ISSN 0103-5150

Fisioter. Mov., Curitiba, v. 29, n. 3, p. 553-560, Jul./Set. 2016

Licenciado sob uma Licença Creative Commons

DOI: http://dx.doi.org.10.1590/1980-5918.029.003.A013

\title{
Clinical profile of newborns undergoing physical therapy in a neonatal intensive care unit
}

\author{
Perfil clínico dos recém-nascidos que realizaram \\ fisioterapia em uma unidade neonatal
}

\author{
Graziela Ferreira Biazus $^{[a]}$, Cidia Cristina Kupke ${ }^{[b, c]^{*}}$ \\ [a] Universidade Federal de Ciências da Saúde de Porto Alegre (UFCSPA), Porto Alegre, RS, Brazil \\ [b] Universidade Federal de Santa Maria (UFSM), Santa Maria, RS, Brazil \\ [c] Centro Universitário Metodista IPA (IPA), Porto Alegre, RS, Brazil
}

\begin{abstract}
Introduction: In neonatal therapy units, physical therapy is directed toward integral baby care. Objective: To describe the profile of newborns (NBs) hospitalized in a Neonatal Intensive Care Unit (NICU). Methods: Retrospective documentary study with data collection from medical records from July 2011 to July 2013. The sample consisted of NBs who performed motor and respiratory therapy. Data were grouped into five categories according to birth weight $(\leq 1000 \mathrm{~g}, 1001-1500 \mathrm{~g}, 1501-2000 \mathrm{~g}, 2001$ $2500 \mathrm{~g}, \geq 2501 \mathrm{~g}$ ). Results: total of 1,884 newborns were admitted to the NICU within the stipulated period, 168 (13.9\%) underwent physical therapy. Of the 168 NBs who underwent physical therapy, 137 were born in the hospital (81.5\%) and 31 were transferred there (18.5\%); 17 of these babies died during the neonatal hospital stay $(10.1 \%)$. All newborns of the extremely low birth weight group $(\leq 1000 \mathrm{~g})$ required mechanical ventilation, $72.7 \%$ non-invasive ventilation and $16.6 \%$ high-frequency oscillatory ventilation. The occurrence of pneumothorax in the extremely low birth weight group was $13.8 \%$ and $16 \%$ in the group with birth weight 1001-1500g. Conclusion: Infants with low birth weight $(<2500 \mathrm{~g})$
\end{abstract}

*GFB: MS, e-mail: gbiazus@hotmail.com
CCK: BS, e-mail: cidiakupke@hotmail.com

Fisioter Mov. 2016 July/Sept.;29(3):553-60 
constituted the profile of NBs who underwent physical therapy, which was directly related to higher incidence of death and pneumothorax, as well as increased use of mechanical and non-invasive ventilation.

Keywords: Physical Therapy. Newborn. NICU.

\section{Resumo}

Introdução: Nas unidades de terapia neonatal, o tratamento fisioterapêutico visa ao cuidado integral do bebê. Objetivo: Descrever o perfil dos recém-nascidos (RNs) internados em uma UTI Neonatal. Métodos: Estudo retrospectivo documental com coleta de dados nos prontuários no período de julho de 2011 a julho de 2013. Pertencem à amostra os RNs que realizaram fisioterapia motora e respiratória. Os dados foram agrupados em cinco categorias de acordo com o peso ao nascimento $(\leq 1.000 \mathrm{~g}, 1.001-1.500 \mathrm{~g}, 1.501-2.000 \mathrm{~g}, 2.001-2.500 \mathrm{~g}$, $\geq 2.501$ g). Resultados: De um total de 1.884 RNs internados na Unidade de Internação Neonatal do Hospital de Clínicas de Porto Alegre no período estipulado, 168 (13,9\%) realizaram fisioterapia. Dos 168 RNs que realizaram fisioterapia, 137 nasceram neste hospital (81,5\%) e 31 foram transferidos para o mesmo (18,5\%); sendo que 17 desses bebês foram a óbito durante o período de internação neonatal $(10,1 \%)$. Todos os RNs do grupo extremo baixo peso $(\leq 1.000 \mathrm{~g})$ necessitaram de ventilação pulmonar mecânica, $72,7 \%$ de ventilação não invasiva e 16,6\% de ventilação mecânica de alta frequência. A ocorrência de pneumotórax no grupo de extremo baixo peso foi 13,8\% e no grupo com peso de nascimento entre 1.001-1.500g foi de 16\%. Conclusão: Bebês com baixo peso ao nascimento $(<2.500 \mathrm{~g})$ constituíram o perfil dos RNs que receberam atendimento de fisioterapia, sendo estes diretamente relacionados com maior incidência de óbito, pneumotórax, maior uso de ventilação pulmonar mecânica e ventilação não invasiva.

Palavras-chave: Fisioterapia. Recém-Nascido. UTI Neonatal.

\section{Introduction}

In neonatal physical therapy care units the aim is to improve pulmonary conditions, reduce airway resistance and increase lung compliance in order to reduce the respiratory workload imposed on newborns (NBs), aiming to improve the respiratory mechanics and neuromotor development (1).

Some of the indications for physical therapy in preterm and term neonates are the aspiration syndromes, respiratory distress syndrome, pneumonia, atelectasis and prevention of mechanical ventilation complications (2). Thus, through bronchial clearance and pulmonary re-expansion techniques, physical therapy can provide improved respiratory function in order to facilitate gas exchange, correct the ventilation-perfusion ratio and prevent or treat pulmonary complications (3).

The literature states that babies who are born prematurely are more likely to have neuromotor dysfunctions, as they are more susceptible to periventricular hemorrhage and periventricular leukomalacia (4).
Data from the Brazilian National Health System (SUS) classifies newborns according to gestational age: preterm, less than 37 weeks of gestational age; term, between 37 and 41 weeks and 6 days of gestation; post-term, more than 42 weeks of gestational age (5). Regarding the criteria of risk, the Ministry of Health classified newborns born with less than $2500 \mathrm{~g}$ as underweight; those born weighing less than $1500 \mathrm{~g}$ as very low birth weight and newborns with birth weight less than $1000 \mathrm{~g}$ as extremely low weight (6).

Newborns of extreme low weight or extreme prematurity are more immature and, therefore, suffer more frequent and more serious complications. They are at high risk of developing neuromotor and sensory deviations and sequelae. The most common consequences are: developmental delays, learning disabilities, behavioral disorders and cerebral palsy (7).

The aims of this study were to describe the profile of newborns that underwent physical therapy and to relate the neonatal care with birth weight in a Neonatal Intensive Care Unit (NICU) in the period July 2011 to July 2013. 
Methods

This was a quantitative, descriptive and retrospective documentary study. It was approved by the Research Ethics Committee of the Hospital de Clinicas de Porto Alegre (HCPA), under authorization number 130,452 .

The population consisted of newborns admitted to the neonatal inpatient unit of HCPA. The sample was composed of the NBs who received respiratory and/or motor physical therapy in this institution, from July 2011 to July 2013.

The mean number of babies hospitalized in the neonatal unit per month was 78.5. Of these, $13 \%$ underwent respiratory and/or motor physical therapy. The sample size was calculated to be 160 babies over the period of two years, using a sampling error of $5 \%$ and $95 \%$ confidence level. The sample size calculation was performedusing the SAS 9.3 program.

For the data collection, a survey was conducted in the medical records. The variables recorded were: birth weight (in grams), gestational age (in weeks), Apgar at the first and fifth minute $(0-10)$, gender (male and female), mode of delivery (cesarean and vaginal), use of exogenous surfactant (yes or no), day of life that physical therapy began (days), use of mechanical ventilation (yes or no), noninvasive ventilation (yes or no), high frequency ventilation (yes or no), inhaled nitric oxide (yes or no), length of hospitalization in the unit (in days), reason for physical therapy request (atelectasis, mucus retention, surgery or motor stimulation), hospital discharge condition (cured or in treatment) and death during hospitalization (yes or no).

Inclusion criteria were newborns hospitalized in the NICU and receiving respiratory and/or motor physical therapy from July 2011 to June 2013. The exclusion criterion was not having undergone respiratory and/or motor therapy during the period stipulated.

Data were grouped into five categories according to birth weight $(\leq 1,000 \mathrm{~g}, 1001-1500 \mathrm{~g}, 1501-2000 \mathrm{~g}$, 2001-2500g, $\geq 2501 \mathrm{~g}$ ), birth weight being the best default predictor forthe immediate and future health of the newborn (8). The variables were analyzed using mean and standard deviation for the continuous variables and simple frequency for the categorical variables (9).

\section{Results}

Of the total of 1,884 newborns admitted to the NICU, within the stipulated period, 168 (13.9\%) underwent respiratory and/or motor therapy. Table 1 shows the relationship between the percentage of NBs and birth weight. Table 2 shows the characteristics of the sample according to birth weight.

Table 1 - Relationship between the percentage of NBs and birth weight (g)

\begin{tabular}{ccc}
\hline Weight (g) & Newborns & $\%$ \\
\hline$\leq 1000$ & 36 & 21.43 \\
$1001-1500$ & 25 & 14.88 \\
$1501-2000$ & 19 & 11.3 \\
$2001-2500$ & 15 & 8.93 \\
$\geq 2501$ & 73 & 43.45 \\
\hline Total & 168 & 100 \\
\hline
\end{tabular}


Table 2 - Characterization of the sample according to birth weight (g)

\begin{tabular}{|c|c|c|c|c|c|}
\hline Caracteristics & $\leq 1000 \mathrm{~g}$ & $1001-1500 \mathrm{~g}$ & $1501-2000 \mathrm{~g}$ & $2001-2500 \mathrm{~g}$ & $\geq 2501 \mathrm{~g}$ \\
\hline 1-minute Apgar* & $4.58( \pm 2.4)$ & $4.92( \pm 2.0)$ & $5.58( \pm 2.2)$ & $6.25( \pm 2.3)$ & $6.28( \pm 2.4)$ \\
\hline 5-minute Apgar* & $7.36( \pm 1.6)$ & $6.96( \pm 1.5)$ & $7.82( \pm 1.4)$ & $7.42( \pm 2.2)$ & $8.12( \pm 1.4)$ \\
\hline Male sex & $17(47.2 \%)$ & $13(52 \%)$ & $13(68.4 \%)$ & $6(40 \%)$ & 48 (65.7\%) \\
\hline GA (weeks)* & $26.9( \pm 1.3)$ & $28.4( \pm 1.1)$ & $33.2( \pm 1.6)$ & $36( \pm 2)$ & $38.3( \pm 1.6)$ \\
\hline$B W(g)^{*}$ & $791.5( \pm 85.7)$ & $1183.4( \pm 121.0)$ & $1766( \pm 110.16)$ & $2244( \pm 137.8)$ & $3208.9( \pm 430.3)$ \\
\hline Exogenous surfactant & $36(100 \%)$ & $20(80 \%)$ & $5(26.3 \%)$ & $3(20 \%)$ & $5(6.8 \%)$ \\
\hline Vaginal & $14(38.8 \%)$ & $14(56 \%)$ & $6(31.5 \%)$ & $5(33.3 \%)$ & $27(36.9 \%)$ \\
\hline Days of began physiotherapy* & $19.8( \pm 14.6)$ & $17.2( \pm 10.8)$ & $24.4( \pm 16.0)$ & $11.2( \pm 8.7)$ & $13.4( \pm 9.5)$ \\
\hline Use of MV & $36(100 \%)$ & $17(68 \%)$ & $13(68.4 \%)$ & $8(53.3 \%)$ & $48(65.7 \%)$ \\
\hline Use of NIV & $26(72.2 \%)$ & $25(100 \%)$ & $\begin{array}{l}9 \\
(47.3 \%)\end{array}$ & $\begin{array}{l}7 \\
(46.6 \%)\end{array}$ & $\begin{array}{l}9 \\
(12.3 \%)\end{array}$ \\
\hline Use of HFOV & $6(16.6 \%)$ & $2(8 \%)$ & 0 & 0 & $2(2.7 \%)$ \\
\hline Use ofiNO & $4(11.1 \%)$ & $1(4 \%)$ & $1(21 \%)$ & $1(6.6 \%)$ & $10(-13.60 \%)$ \\
\hline Pneumothorax & $5(13.8 \%)$ & $4(16 \%)$ & $2(10.5 \%)$ & $1(6.6 \%)$ & $2(2.7 \%)$ \\
\hline Days of hospitalization in NICU* & $78.3( \pm 32.3)$ & $75.7( \pm 20.0)$ & $64.5( \pm 24.1)$ & $31.2( \pm 16.5)$ & $39.0( \pm 17.3)$ \\
\hline Death & $11(30.5 \%)$ & $1(4 \%)$ & $1(5.2 \%)$ & $1(6.7 \%)$ & $3(4.2 \%)$ \\
\hline
\end{tabular}

Note:*Mean and standard desviation. GA: gestacional age; BW: birth weight; MV: mechanical ventilation;NIV: non-invasive ventilation; HVOF: high-frequency oscillation ventilation; iNO:inhaled nitric oxide; NICU: neonatal intensive care unit.

Of the 168 infants that underwent physical therapy, 137 were born at the obstetric center of HCPA (81.5\%) and 31 were transferred to HCPA (18.5\%); 17 of these babies died during the neonatal hospital stay $(10.1 \%)$. Table 3 presents the reasons for the therapy request, these being: atelectasis, mucus retention, surgery and motor stimulation

Table 3 - Reason for physical therapy request according to birth weight (g)

\begin{tabular}{cccccc}
\hline Caracteristics & $\mathbf{1 0 0 0 g}$ & $\mathbf{1 0 0 1 - 1 5 0 0 g}$ & $\mathbf{1 5 0 1 - 2 0 0 0 g}$ & $\mathbf{2 0 0 1 - 2 5 0 0 g}$ & $\geq \mathbf{2 5 0 1} \mathbf{g}$ \\
Atelectasis & $9(25 \%)$ & $5(20 \%)$ & $4(21 \%)$ & $3(20 \%)$ & $20(27.3 \%)$ \\
Mucusretenion & $27(75 \%)$ & $20(80 \%)$ & $11(57.8 \%)$ & $7(46.6 \%)$ & $45(61.6 \%)$ \\
Surgery & $1(2.7 \%)$ & 0 & 0 & $1(6.6 \%)$ & $4(5.4 \%)$ \\
Motor & $1(2.7 \%)$ & 0 & $5(26.3 \%)$ & $5(33.3 \%)$ & $13(17.8 \%)$ \\
\hline
\end{tabular}

Table 4 presents the data on hospital discharge condition according to birth weight. The discharge condition was categorized as "cured", when the infant did not require oxygen therapy, physical therapy or airway aspiration in the domicile, and "in treatment", when there was a need for care, such as oxygen therapy, physical therapy or airway suctioning.

Feeding route, whether oral or orogastric tube, at discharge from the neonatal unit was recorded.

Table 4 - Hospital discharge condition according to birth weight (g)

\begin{tabular}{cccccc}
\hline Hospital dischardecondition & $\mathbf{1 0 0 0 g}$ & $\mathbf{1 0 0 1 - 1 5 0 0 g}$ & $\mathbf{1 5 0 1 - 2 0 0 0 g}$ & $\mathbf{2 0 0 1 - 2 5 0 0 g}$ & $\geq \mathbf{2 5 0 1 g}$ \\
\hline Cured & $18(72 \%)$ & $21(87.5 \%)$ & $12(66.6 \%)$ & $13(92.8 \%)$ & $57(78 \%)$ \\
In treatment & $7(28 \%)$ & $3(12.5 \%)$ & $6(33.4 \%)$ & $1(7.2 \%)$ & $13(22 \%)$ \\
Alimentation & & & & & \\
Oral & $15(60 \%)$ & $21(64 \%)$ & $9(50 \%)$ & $12(85.7 \%)$ & $56(76.7 \%)$ \\
Orogastric tube & $10(40 \%)$ & $3(36 \%)$ & $9(50 \%)$ & $2(14.3 \%)$ & $14(23.3 \%)$ \\
\hline Total & $\mathbf{2 5 ( 1 0 0 \% )}$ & $\mathbf{2 4 ( 1 0 0 \% )}$ & $\mathbf{1 8 ( 1 0 0 \% )}$ & $\mathbf{1 4 ( 1 0 0 \% )}$ & $\mathbf{7 3 ( 1 0 0 \% )}$ \\
\hline
\end{tabular}




\section{Discussion}

In the sample stratified by birth weight, it was observed that the death percentage was inversely proportional to gestational age (GA). The group with birth weight $\leq 1000 \mathrm{~g}$ had a higher incidence of death, 11 (30.5\%), compared to the other groups. The Apgar score less than 7 at 1 and 5 minutes is considered a risk factor for mortality (10). The study by Piccoli et al. (11) also showed a high incidence of prematurity and low birth weight with consequent morbidity and mortality.

Silva et al. (12) found that variables associated with death until the 27th day of life were type of delivery, notusing antenatal corticosteroids, preeclampsia, birth weight $<2500$ g, Apgar score $<7$ at 5 minutes, endotracheal intubation, and notusing exogenous surfactant. For these authors, death was determined by the conditions of the pregnancy, delivery and the newborn.

The group considered extremely low birth weight, or birth weight $\leq 1000 \mathrm{~g}$ presented a mean gestational age of 26.9 weeks and the group with birth weight 1001-1500g presented a mean gestational age of 28.4 weeks. The general immaturity can lead to dysfunction in any organ or bodily system, and the premature neonate may also suffer impairment or complications throughout their development.

All 36 infants of the extremely low birth weight group required respiratory support, with $72.7 \%$ receiving non-invasive ventilation (NIV) and $16.6 \%$ high-frequency oscillatory ventilation (HFOV). Of the group with birth weight $1001-1500 \mathrm{~g}, 68 \%$ of the newborns required respiratory support, with $100 \%$ NIV and 8\% HFOV. A multicentriccohort study by Vendettuoli et al. (13) in Italy, including 2,465 preterm infants with GA between 23 and 30 weeks, showed a reduction in mechanical ventilation and an increase in the use of NIV, accompanied by a decrease in mortality and bronchopulmonary dysplasia. This highlights the importance of NIV use in newborns with extremely low and low birth weight.

In newborns, the use and duration of MV are associated with several complications, including infection, pneumothorax, bronchopulmonary dysplasia, increased risk of death and poor development prognosis. Therefore, it is important to minimize the use of MV and give preference to the use of NIV whenever possible. However, for premature newborns with pulmonary complications MV is still often required.
In such cases, the proposal is not to vent aggressively and to use for only a short period (14).

Several mechanical ventilation modes are available for preterm infants. The choice of method and strategy should be based on knowledge of the physiology and pathophysiology of the disorder presented and the prevention of lung damage. Non-invasive ventilation can be used for treating atelectasis, oxygenation improvement, reducing the respiratory workload, preventing alveolar collapse and improving secretion removal efficiency (15).

According to the study by Tsai et al. (16), mechanical ventilation for more than 15 days increases the risk of cerebral palsy disorder and attention deficit/ hyperactivity disorder, even without injury to the brain. It is known that respiratory support via mechanical ventilation is important and necessary for the survival of newborns, however, poses risks (14). The GA was described by Favero et al. (17) as a factor that affectsextubation failure and reintubation, being inversely proportional to the age. This may be related to the anatomical and physiological immaturity of the respiratory system (18).

When the patient is undergoing MV, there is accumulation of secretion leading to increased airway resistance and respiratory workload, changes in ventilation perfusion and consequent atelectasis, delaying the MV weaning process (19). Atelectasis is a frequent lung condition that can increase the predisposition of the child to infectious complications and the need for increased ventilatory support (oxygen, mechanical and/or non-invasive ventilation) (20). Respiratory therapy,including bronchial hygiene techniques and positioning in the bed, has been shownto be an important resource in the MV weaning process (21).

Thoracoabdominal rebalancing is a technique that aims to encourage ventilation and promote the removal of pulmonary secretions and clearance of the upper airways, through the reorganization of respiratory muscle synergism, which is lost in lung disorders. It is based on positioning, mobilization of costovertebral and costochondral joints, muscle stretching, manual support to increase intra-abdominal pressure and myofascial maneuvers conducted to minimize the use of accessory muscles, re-educating the respiratory system that is overloaded in neonatal pathologies (22).

The occurrence of pneumothorax in the extremely low birth weight group was $13.8 \%$ and $16 \%$ in the group with birth weight 1001-1500g. Pneumothorax 
is more common in the first 48 hours of life, especially among preterm newborns (23). It can be associated with respiratory distress syndrome, meconium aspiration, pulmonary hypoplasia, and even ventilatory support (24).

In the present study, the physical therapy care commencedaround the second week of life, varying bya few days between groups according to birth weight. The main reasons for the physical therapy request were due to atelectasis and retention of pulmonary secretions. It was also observedthat there were more requests for care in the newborns weighing up to $2500 \mathrm{~g}$, compared to the group with birth weight equal to or above $2501 \mathrm{~g}$.

Among the complications associated with low birth weight and extremely low birth weight there are neonatal infections, respiratory distress syndrome, retinopathy of prematurity, perinatal anoxia, periintraventricular hemorrhage, periventricular leukomalacia, metabolic disorders, necrotizing enterocolitisand patent ductus arteriosus, with the development of bronchopulmonary dysplasia in the long term, this being one of the most important chronic complications in preterm survivors (25).

It was found that approximately $20 \%$ of the newborns required some assistance,such as oxygen therapy, physical therapy or airway suctioning,after discharge from the neonatal unit. For this reason it is important to inform the family about the care that will be needed after leaving the hospital. Oxygen therapy in the domicile is a growing practice for pediatric patients, especially in cases of bronchopulmonary dysplasia, cystic fibrosis and bronchiolitis obliterans (26).

It is important to monitor the psychomotor development in premature newborns after hospital discharge. The most common sequelae in the first years of life are: cerebral palsy, mental retardation and sensorineural losses, such as visual impairment and hearing. There must be individualized supportive care that respects the personalityof the NB and encourages the participation of the family (27). Multidisciplinary outpatient treatment,including physical therapy, speech therapy, psychology and occupational therapy, is critical in trying to prevent or minimize the presentation of motor and cognitive development deficits.

Family-centered care is an approach that contributes to competence in the care and the well-being of the child. Among its structuring aspects is the establishment of bonds, for which communication is essential (28).

The physical therapy rehabilitation was designedfor the evaluation and prevention of kinetic functional changes due to the MV and NIV intervention(29). An evaluationshould be performed to determine the care priority of the NB, taking into account the individual characteristics. The pregnancy history and labor conditionsshould be considered, as well as the neurological and respiratory evaluation. The overall aims of the care include the diagnosis of alterations in psychomotor development, prevention of deviations from the norm,provision of sensorimotor stimulation, prevention or treatment of respiratory and/or musculoskeletal complications andthe provision of information and guidance for the parents.

Integral care for babies and their families has become one of the best practices observed during hospitalization in NICUs. Since 1999, the Ministry of Health has been implementing the Kangaroo Method, which is a humanized care policy for very low birth weight newborns. The method proposes the humanization of neonatal care based on four basic principles: sensitivity toward the baby and his/her family, respect for individualities, promoting skin to skin contact through the Kangaroo position and involving the mother in caring for her child. Babies participating in the Kangaroo method have better sensorimotor responses, lower degrees of stress, and better spontaneous reflex responses (30).

\section{Conclusion}

Babies with low birth weight $(<2500 \mathrm{~g})$ constituted the profile of NBs who underwent physical therapy, which is directly related to higher incidence of death and pneumothorax and the increased use of mechanical and non-invasive ventilation. The main reasons for the physical therapy request were atelectasis and retention of pulmonary secretions. The physical therapist should provide humane care to the newborn, and be aware of integral baby care.

A limitation observed in this study was that the data related to some variables could not be evaluated, such as mechanical ventilation, ventilator-associated pneumonia, ventilator settings for extubation and extubation failure rate. Thus, it is suggested that further prospective studies be conducted with postdischarge follow-ups. 


\section{References}

1. Vasconcelos GAR, Almeida RCA, Bezerra AL. Repercussions of physiotherapy in the Neonatal Intensive Care Unit. Fisio e Movimento . 2011;24(1):65-73.

2. Nicolau CM, Pigo JDC, Bueno M, Falcão MC. Pain assessment in premature infants during respiratory physiotherapy. Rev Bras Saude Mater Infant. 2008;8(3):285-90.

3. Abreu LC, Angheben JMM, Braz PF, Oliveira AG, Falcão MC, Saldiva PHN. E ect of the neonatal physiotherapy in the heart rate in preterm infant with respiratory distress syndrome after replacement of exogenous surfactant. Arq Med ABC. 2006;31(1):5-11.

4. Gonçalves MCP. Prematuridade: desenvolvimento neurológico e motor - avaliação e tratamento. Rio de Janeiro: Revinter; 2012. Portuguese.

5. Datasus. Defenições. 2015 [cited Apr 15]. Available from: http://tinyurl.com/jddvkel. Portuguese.

6. Ministério da Saúde, Secretaria de Vigilância em Saúde/ Secretaria de Atenção à Saúde. Manual de vigilância do óbito infantil e fetal e do comitê de prevenção do óbito infantil e fetal. 2nd ed. Brasília: Ministério da Saúde; 2009. Portuguese.

7. Pavão SL, Arnoni JLB, Oliveira AKC, Rocha NACF. Impact of a virtual reality-based intervention on motor performance and balance of a child with cerebral palsy: a case study. Rev Paul Pediatr. 2014;32(4):389-94.

8. Abreu LC, Souza AMB, Oliveira AG, Selestrin CC, Guerra MSB, Ferreira C, et al. Incidência de hemorragia peri-intraventricular em recém-nascidos pré-termo e a relação com o peso ao nascer. Rev. bras. crescimento desenvolv. hum. 2007;17(2):24-30.

9. Callegari-Jacques SM. Bioestatística: princípios e aplicações (Biostatistics: principles and applications). Porto Alegre (Brazil): Artmed; 2007. Portuguese.

10. Bittencourt RM, Gaíva MAM. Mortalidade neonatal precoce relacionada a intervenções clínicas. Rev Bras Enferm. 2014;67(2):195-201.

11. Piccoli A, Soares CRS, Costa G, Silveira JL, Fiatt MP, Cunha RS. Perfil clínico de neonatos de muito baixo peso internados em uma Unidade de Tratamento Intensivo Neonatal. Rev. HCPA \& Fac. Med. Univ. Fed. Rio Gd. do Sul . 2012;32(4):412-19.
12. Silva CF, Leite AJM, Almeida NMGS, Leon ACMP, Olofin I, et al. Fatores associados ao óbito neonatal de recém-nascidos de alto risco: estudo multicêntrico em Unidades Neonatais de Alto Risco no Nordeste brasileiro. Cad Saude Publica. 2014;30(2):355-68.

13. Vendettuoli V, Bellù R, Zanini R, Mosca F, Gagliardi L. Changes in ventilator strategies and outcomes in preterm infants. Arch Dis Child Fetal Neonatal. 2014;99(4):321-4.

14. Nicolau CM, Andrade LB (Org). PROFISIO. Programa de Atualização em Fisioterapia Pediátrica e Neonatal: Cardiorrespiratória e Terapia Intensiva. Ciclo 1. Porto Alegre (Brazil): Artmed. 2012; 1(1). Portuguese.

15. Loh LE, Chan YH, Chan I. Noninvasive in children: a review. J Pediatr. 2007;83(2):91-9.

16. Tsai WH, Hwang YS, Hung TY, Weng SF, Lin SJ, Chang WT. Association between mechanical ventilation and neurodevelopment disorders in a nationwide cohort of extremely low birth weight infants. Res Dev Disabil. 2014;35(7):1544-50.

17. Fávero RA, Schuster RC, Wojahn VW, Tartari JL. Incidência e principais fatores associados à falha na extubação em recém-nascidos prematuros. Pediatria. 2011;33(1):13-20.

18. Costa ACO, Schettino RC, Ferreira SC. Fatores preditivos para falha de extubação e reintubação de recémnascidos submetidos à ventilação pulmonar mecânica. Rev Bras Ter Intensiva. 2014;26(1):51-6.

19. Nicolau CM, Andrade LB (Org). PROFISIO. Programa de Atualização em Fisioterapia Pediátrica e Neonatal: Cardiorrespiratória e Terapia Intensiva. Ciclo 2. Porto Alegre (Brazil): Artmed. 2012; 1(2). Portuguese.

20. Johnston C, Carvalho WB. Atelectasias em pediatria: mecanismos, diagnósticos e tratamento. Rev Assoc Med Bras. 2008;54(5):455-60.

21. Pessina DC, Costa TCM, Cavenaghi OM, Goraieb L, Corrêa PR, Croti UA. Plicatura diafragmática após lesão do nervo frênico em operação de Glenn: relato de caso. Fisioter Mov. 2008;21(1):73-8.

22. Roussenq KR, Scalco JC, Rosa GJ, Honório GJS, Schivinski CIS. Reequilíbrio tóracoabdominal em recémnascidos prematuros: efeitos em parâmetros cardiorrespiratórios, no comportamento, na dor e no desconforto respiratório. Acta Fisiatr. 2013;20(3):118-23. 
23. Wei YH, Lee CH, Cheng HN, Tsao LT, Hsiao CC. Pigtail Catheters Versus Traditional Chest Tubes for Pneumothoraces in Premature Infants Treated in Neonatal Intensive Care Unit. Pediatr Neonatol. 2014;55(5):376-80.

24. Cloherty JP, Stark AR, Eichenwald EC. Manual of Neonatal Care. 7th ed. Philadelphia: Lippincott Williams \& Wilkins; 2012.

25. Tapia JL, Agost D, Alegria A, Standen J, Escobar M, Grandi C, et al. Displasia broncopulmonar: incidência, fatores de risco e utilização de recursos em uma população sul-americana de recém-nascidos de muito baixo peso. J Pediatr. 2006;82(1):15-20.

26. Adde FV, Alvarez AE, Barbisan BN, Guimarães BR. Recomendações para oxigenoterapia domiciliar prolongada em crianças e adolescentes. J Pediatr. 2013;89:6-17.

27. Neves LAT, Fronio JS, Araújo JL, Lupatini PRM. Por que prestar assistência ao prematuro? Rev Med Minas Gerais. 2012;22(7):57-62.

28. Silva LM, Tavares LAM, Gomes CF. Dificuldades na amamentação de lactentes prematuros. Rev Disturb Comun. 2014;26(1):50-9.

29. Johnston C, Zanetti NM, Comaru T, Ribeiro SNS, Andrade LB, Santos SLL. I Recomendação brasileira de fisioterapia respiratória em Unidade de Terapia Intensiva Pediátrica e Neonatal. Rev Bras Ter Intensiva. 2012;24(2)119-29.

30. Franco MP, Alves CP. The impact of the method Kangaroo Mother Care in the learning process of low-birthweight preterm infants: A literature review. Cad Ter Ocup UFSCar. 2014;22(1):163-74.

Received in 07/28/2014

Recebido em 28/07/2014

Approved in 10/22/2015

Aprovado em 22/10/2015 